\title{
A COMPARISON OF 'GRASSLANDS PITAU' AND 'HUIA' WHITE CLOVERS IN OTAGO
}

\author{
I. R. McDonald and N. A. Cullen
}

Invermay Agricultural Research Centre, Ministry of Agriculture

\& Fisheries, Private Bag, Mosgiel

\section{Abstract}

Pitau and Huia white clovers were sown with two rates of Ruanui, Ariki and Manawa ryegrass on high fertility soil at Invermay Agricultural Research Centre and lower fertility soil at Traquair. Although clover establishment in the Pitau white clover treatments was comparable with, or superior to that in the Huia treatments, the latter tended to have a denser growth habit, particularly during spring. Overall, there was little difference in total annual dry matter production between treatments but clover yields varied considerably in all trials. Huia clover dry matter production was superior to Pitau in the first two years but in later years the position was reversed.

The production of Pitau clover was higher than Huia in autumn, but Huia outyielded Pitau in spring and summer on most occasions. Pitau appeared to be adversely affected by ryegrass competition.

Although Pitau white clover failed to demonstrate any marked superiority over Huia white clover either in mowing or grazing trials, its improved performance in later years suggested there could be somc merit in sowing mixtures of the two.

\section{INTRODUCTION}

Huia white crover is a standard component of nearly all pasture mixtures sown in New Zealand. Its production during late spring and summer is high but cool season production is low. In an endeavour to overcome this shortcoming, Huia was crossed with a Spanish white clover and observations made on the performance of various crosses (Barclay, 1969). Seed of one of these, designated 'Grasslands 4700', was released in 1966 to various research establishments for testing under a wide range of environments. Preliminary results of these trials were presented at the N.Z. Grassland Association 1969 Conference (Lambert et al., 1969; Weeda et al., 1969) . While the performance of 4700 was promising in the North Island, preliminary results from South Island trials were not particularly encouraging.

This paper presents further results from trials conducted at two sites in Otago. Since these trials were completed, 'Grasslands 4700' has been released for multiplication under the name of Pitau. This name is therefore used throughout. 


\section{EXPERIMENTAL}

Mowing trials were laid down at Traquair $(25 \mathrm{~km}$ west of Mosgiel, at an altitude of $400 \mathrm{~m}$ ) and Invermay (near Mosgiel, on the Taieri Plain) on September 23, 1966, and January 30, 1967, respectively, and a grazing trial at Invermay on February 1, 1967.

\section{Soll and Climate}

The soil at Invermay is a Wingatui recent alluvial silt loam of high fertility, while that at Traquair is a Wehenga upland yellowbrown earth of medium fertility. Rainfall at both sites is approximately $650 \mathrm{~mm}$ per year. Mild droughts are sometimes experienced at both sites during summer and light snowfalls are not uncommon in winter at Traquair.

Design, Layout and Managerment of Trials

\section{M owing Trials}

A randomized block layout with four replicates was useci in the mowing trials. Plot size was $9.1 \times 1.8 \mathrm{~m}$.

Both clover cultivars were sown at a seeding rate of $3.3 \mathrm{~kg} / \mathrm{ha}$ viable seed, with two seeding rates of Ruanui and Ariki ryegrass - 5.6 and $22.4 \mathrm{~kg} / \mathrm{ha}$. Manawa ryegrass sown at similar seeding rates was also included in the Invermay mowing trial. The seed was broadcast along with basal fertilizers and raked in.

The herbage was cut when it reached a height of approximately $12 \mathrm{~cm}$, down to approximately $3 \mathrm{~cm}$. The mowing and clippings returned technique was used (Lynch, 1947).

\section{Grazing Trial}

Seed of the two clovers was sown at $3.3 \mathrm{~kg} / \mathrm{ha}$ with $16.8 \mathrm{~kg} / \mathrm{ha}$ Ruanui or Ariki ryegrass, in a randomized paddock layout with four replicates. Paddock size was $20 \times 10 \mathrm{~m}$.

Production was measured from two $4.04 \mathrm{~m}^{2}$ frames per paddock, using the enclosure technique, (Lynch, 1947). Paddocks were mob-grazed with sheep and production estimates made whenever herbage within the frames reached a height of approximately $12 \mathrm{~cm}$. Both grazing and cutting aimed to leave a stubble of about $3 \mathrm{~cm}$.

Establishment counts, density and yield data were recorded from all trials. 
RESULTS

In this paper it is not possible to present all data collected, so a selection has been made to illustrate the main effects.

ESTABLISHMENT

Clover (Table 1) and ryegrass establishment was satisfactory at all sites.

TABLE 1: ESTABLISHMENT COUNTS

(Number of clover plants/m')

\begin{tabular}{|c|c|c|c|c|}
\hline & & Huia & Pitau & $C V \%$ \\
\hline \multicolumn{5}{|l|}{ Mowing Trials } \\
\hline Traquair (counted $8 / 12 / 66$ ) & , & $294 \mathrm{~B} *$ & $465 \mathrm{~A}$ & 12.5 \\
\hline Invermay (counted $14 / 3 / 67$ ) & , & 354 a & $364 a$ & 15.7 \\
\hline \multicolumn{5}{|l|}{ GRAZING TRIAL } \\
\hline Invermay (counted $16 / 3 / 67$ ) & -- & 335 a & 326 a & 6.0 \\
\hline
\end{tabular}

*Duncan's multiple range test: Means without a common letter differ significantly (lower case, $\mathrm{P}<0.05$; upper case, $\mathrm{P}<0.01$ ).

There was no significant difference in the number of Huia and Pitau clover plants in either of the Tnvermay trials but at Traquair significantly more clovers were present in the Pitau treatments. Neither ryegrass variety nor seeding rate had any significant effect on clover establishment.

\section{Clover Growth habit}

Observations taken at various times indicated that Pitau clover was taller, generally larger in leaf but not as dense as Huia. The latter observation was supported by point analysis measurements taken on four occasions (Table 2).

Huia clover density, as determined by point analysis, was significantly greater than that of Pitau at all four pointings taken at Traquair, despite the fact that establishment counts indicated that there were fewer Huia clover plants present. In the Invermay mowing trial, Huia clover density was significantly greater than Pitau only during spring. In summer and autumn the density of the two clovers was similar. Under grazing, Huia density was significantly greater than Pitau in November 1968 only,

\section{Herbage production}

Herbage cuts were taken from all trials in the late summer and autumn of 1967 but few differences between treatments were 
TABLE 2: CLOVER DENSITY

(Total hits per 100 points)

\begin{tabular}{|c|c|c|c|c|c|c|}
\hline & & & & Huia & Pitau & $\mathrm{cv} \%$ \\
\hline \multicolumn{7}{|c|}{ MoWING T RIALS } \\
\hline \multicolumn{7}{|c|}{ Traquair: } \\
\hline Sep. 1967 & $\therefore$ & $\ldots$ & $\ldots \cdot$ & $40 \mathrm{a}$ & $31 \mathrm{~b}$ & 27.4 \\
\hline Mar. 1968 & & & & $69 \mathrm{~A}$ & $52 \mathrm{~B}$ & 16.8 \\
\hline Nov. 1968 & $\ldots$ & & . & $86 \mathrm{~A}$ & $69 \mathrm{~B}$ & 14.6 \\
\hline Oct. 1969 & .. & & & $82 \mathrm{a}$ & $72 \mathrm{~b}$ & 14.1 \\
\hline \multicolumn{7}{|l|}{ Invermay: } \\
\hline Sep. 1967 & . & & .... & $\therefore 18 \mathrm{~A}$ & $10 \mathrm{~B}$ & 36.3 \\
\hline Apr. 1968 & $\ldots$ & & & $47 \mathrm{a}$ & $47 \mathrm{a}$ & 22.9 \\
\hline Dec. 1968 & .... & & & $68 \mathrm{a}$ & $68 \mathrm{a}$ & 13.8 \\
\hline Oct. 1969 & & & & $42 \mathrm{~A}$ & $24 \mathrm{~B}$ & 23.0 \\
\hline \multicolumn{7}{|l|}{ GRAZING TRIAL } \\
\hline \multicolumn{7}{|l|}{ Invermay: } \\
\hline Oct. 1967 & . & & . & $6 a$ & $5 \mathbf{a}$ & 27.0 \\
\hline Apr. 1968 & & & . & $17 \mathrm{a}$ & $12 \mathrm{a}$ & 35.0 \\
\hline Nov. 1968 & . & . & & $48 \mathrm{~A}$ & $25 \mathrm{~B}$ & 20.6 \\
\hline Oct. 1969 & .... & $\ldots$ & $\ldots$ & 32 a & $35 \mathrm{a}$ & 28.0 \\
\hline
\end{tabular}

noted. The first full year's production measurements were made in 1967-g.

\section{Total Dry Matter Yields}

In the mowing trial at Traquair and the grazing trial at Invermay, there were no significant differences in total annual dry matter production between Huia and Pitau treatments (Table 3).

In the Invermay mowing trial, total production from the Huia white clover treatments was significantly higher than those sown with Pitau in the first and third years, while Pitau treatments were higher yielding in the second year. In the fourth year, total production from both Huia and Pitau treatments' was similar.

Ryegrass variety influenced total dry matter yields in the Invermay mowing trial. In the first two years total annual production from treatments sown with Ruanui ryegrass was significantly higher than from those sown with Ariki. Total herbage production was significantly lower from treatments sown with Manawa in almost every instance, However, in all trials there were no significant interactions associated with total annual production.

\section{SPECIES YieldS}

Total annual clover and ryegrass yields were recorded from the Traquair trial and the Invermay grazing trial only. No statistical 
TABLE 3: TOTAL HERBAGE DRY MATTER PRODUCTION $(\mathrm{kg} / \mathrm{ha})$

\begin{tabular}{|c|c|c|c|c|c|c|c|}
\hline & & & & & Huia & Pitau & CV\% \\
\hline \multirow{2}{*}{\multicolumn{8}{|c|}{ Traquair: }} \\
\hline & & & & & & & \\
\hline $1967-8$ & $\ldots$ & $\ldots$ & & & 6900 a & $6520 \mathrm{a}$ & 13.9 \\
\hline $1968-9$ & 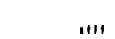 & . & . & 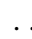 & 6240 a & $6020 \mathrm{a}$ & 7.5 \\
\hline $1969-70$ & $\ldots$ & & . . & & $10780 \mathrm{a}$ & $10740 \mathrm{a}$ & 4.5 \\
\hline 1970-1 & $\ldots$ & . & . & & 8520 a & 8850 a & 9.2 \\
\hline \multicolumn{8}{|l|}{ lnvermay: } \\
\hline $1967-8$ & & .... & & . & $11610 \mathrm{~A}$ & $10560 \mathrm{~B}$ & 4.0 \\
\hline $1968-9$ & in. & . & & & $8680 \mathrm{~B}$ & $9150 \mathrm{~A}$ & 6.2 \\
\hline $1969-70$ & $\ldots$ & & . & & $12420 \mathrm{a}$ & $12030 \mathrm{~b}$ & 3.8 \\
\hline 1970-1 & $\ldots$ & . & & & $10760 \mathrm{a}$ & $10720 \mathrm{a}$ & 6.6 \\
\hline GRAZING & TrIaL & & & & & & \\
\hline \multicolumn{8}{|c|}{ Invermay: } \\
\hline $1967-8$ & & . & . & & $15810 \mathrm{a}$ & $16660 \mathrm{a}$ & 7.1 \\
\hline $1968-9$ & $\ldots$ & 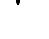 & 6 & . & $9960 \mathrm{a}$ & $9460 \mathrm{a}$ & 6.0 \\
\hline $1969-70$ & & & . & & 14990 a & $14660 \mathrm{a}$ & 4.9 \\
\hline
\end{tabular}

N.B.: Total production includes yields from volunteer species.

analysis of total species yields was possible but a consistent trend emerged. In the first two years, clover production from Huia was higher than Pitau in both trials but in later years the position was reversed in the mowing trial at Traquair, where production from Pitau was considerably higher than from Huia in the final year. Under grazing there was little difference in clover production between the two cultivars in the third year (Table 4). Ryegrass yields tended to fluctuate in inverse proportion to clover content, explaining why total annual dry matter production did not differ significantly.

TABLE 4: TOTAL CLOVER AND RYEGRASS DRY MATTER PRODUCTION

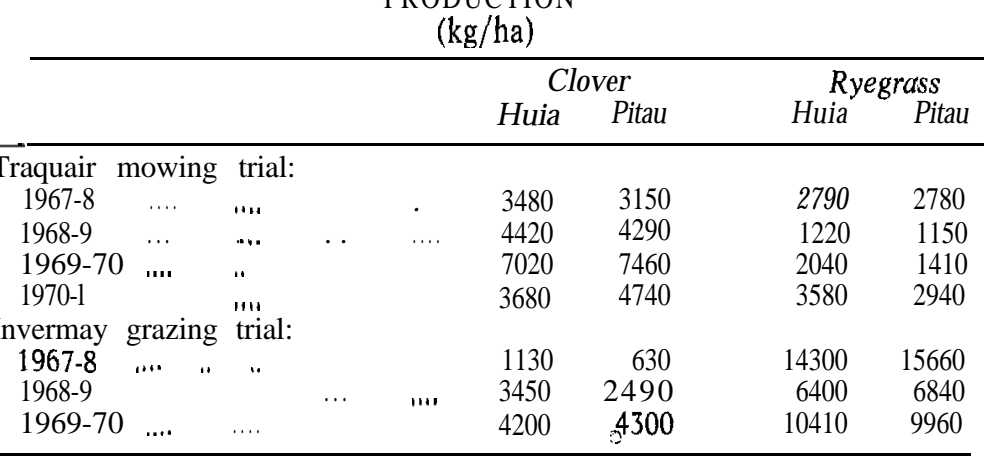


TABLE 5: SEASONAL CLOVER PRODUCTION (kg/ha)

\begin{tabular}{|c|c|c|c|c|c|c|c|c|}
\hline \multicolumn{3}{|c|}{ Traquair Mowing Trial } & \multicolumn{3}{|c|}{ Invermay Mowing Trial } & \multicolumn{3}{|c|}{ Invermay Grazing Trial } \\
\hline Date Cut & Huia & Pitau & Date Cut & Huia & Pitau & Date Cut & Huia & Pitau \\
\hline \multicolumn{9}{|l|}{$1967-8$} \\
\hline $25 / 10 / 67$ & $500 \mathrm{a}$ & $460 \mathrm{a}$ & $14 / 9 / 67$ & $30 \mathrm{~A}$ & $20 \mathrm{~B}$ & $20 / 9 / 67$ & $10 \mathrm{NA}$ & $0 \mathrm{NA}$ \\
\hline $18 / 12 / 67$ & $1510 \mathrm{~A}$ & $1120 \mathrm{~B}$ & $16 / 1 / 68$ & $800 \mathrm{~A}$ & $460 \mathrm{~B}$ & $12 / 1 / 68$ & $210 \mathrm{a}$ & $80 \mathrm{~b}$ \\
\hline $\begin{array}{c}10 / 5 / 68 \\
1968-9\end{array}$ & $740 \mathrm{~b}$ & $850 \mathrm{a}$ & $18 / 3 / 68$ & $730 \mathrm{a}$ & $810 a$ & $5 / 4 / 68$ & $480 \mathrm{a}$ & $300 \mathrm{a}$ \\
\hline $6 / 11 / 68$ & $1320 \mathrm{NA}$ & $1100 \mathrm{NA}$ & $18 / 10 / 68$ & - & & $1 / 10 / 68$ & $220 \mathrm{a}$ & '160a \\
\hline $16 / 1 / 69$ & $1080 \mathrm{NA}$ & $1050 \mathrm{NA}$ & $8 / 1 / 69$ & $830 \mathrm{a}$ & 800 a & $6 / 1 / 69$ & $720 \mathrm{~A}$ & $440 \mathrm{~B}$ \\
\hline $\begin{array}{r}9 \\
1969-10 / 69\end{array}$ & $220 \mathrm{~B}$ & $300 \mathrm{~A}$ & $16 / 4 / 69$ & $350 \mathrm{~B}$ & $500 \mathrm{~A}$ & $20 / 3 / 69$ & $350 \mathrm{a}$ & $380 \mathrm{a}$ \\
\hline $20 / 10 / 69$ & $770 \mathrm{a}$ & $750 \mathrm{a}$ & $16 / 9 / 69$ & $350 \mathrm{~A}$ & 260B & $10 / 9 / 69$ & $160 \mathrm{a}$ & $130 \mathrm{a}$ \\
\hline $21 / 1 / 70$ & $1920 \mathrm{a}$ & $1840 \mathrm{a}$ & $19 / 1 / 70$ & $1050 \mathrm{a}$ & $960 \mathrm{a}$ & $20 / 1 / 70$ & $920 \mathrm{~b}$ & $1030 \mathrm{a}$ \\
\hline $26 / 3 / 70$ & $770 \mathrm{~B}$ & $880 \mathrm{~A}$ & $21 / 5 / 70$ & $190 \mathrm{~B}$ & $410 \mathrm{~A}$ & 7) $4 / 70$ & $300 \mathrm{a}$ & $270 \mathrm{a}$ \\
\hline
\end{tabular}


Seasonal Clover Production

Clover yields from some individual cuts were statistically analysed and these serve to illustrate seasonal clover production. This is shown in Table 5.

In spring Huia clover outyielded Pitau in all trials although the difference was not significant on several occasions.

Huia summer production was significantly higher than that of Pitau in the first year. This trend continued in the two mowing trials but differences were small and did not reach significance. In the grazing trial, Huia significantly outyielded Pitau in the second year but the trend was reversed in the third year.

Autumn Pitau clover production was significantly higher than that of Huia on most occasions in the mowing trials but this was not evident under grazing.

\section{Competitive Effects of Ryegrass}

Pitau clover appeared more sensitive to competition from ryegrass than did Huia (Table 6).

TABLE 6: EFFECT OF RYEGRASS COMPETITION ON CLOVER YIELDS

$$
\text { Traquair } \stackrel{(\mathrm{kg} / \mathrm{ha})}{\text { Mowing Trial }}
$$

\begin{tabular}{|c|c|c|c|c|c|c|c|}
\hline & $1967-8$ & 196 & 88-9 & 196 & $9-70$ & & $70-l$ \\
\hline & Huia Pitau & Huia & Pifau & Huia & Pifau & Huia & Pitau \\
\hline Ruanui & 3460 & 4400 & 4430 & 6970 & 7920 & 4170 & 4940 \\
\hline Ariki & $3490 \quad 2880$ & 4430 & 4140 & 7060 & 7010 & 3180 & 4540 \\
\hline $5.6 \mathrm{~kg}$ & $3770 \quad 3280$ & 4360 & 4320 & 6640 & 7680 & 3220 & 5180 \\
\hline $22.8 \mathrm{~kg}$ & 3180 & 4480 & 4260 & 7390 & 7250 & 4130 & 4310 \\
\hline
\end{tabular}

The yield of Pitau clover was lower in the presence of Ariki ryegrass than Ruanui in each of the four years. In contrast, Huia clover yieids were similar in the two ryegrass treatments, except in the fourth year.

The high ryegrass seeding rate also appeared to suppress Pitau clover and this was particularly noticeable in the fourth year. With the low ryegrass seeding rate, Pitau clover production was considerably better than that of Huia by the fourth year. However, with the high ryegrass seeding rate, Pitau yields were similar to those of Huia and failed to show the improvement noted with the low ryegrass seeding rate. 


\section{DISCUSSION}

In this series of trials, Pitau white clover failed to show any marked superiority over Huia. Total annual production was similar from both clover treatments in most instances. During the first two years after sowing, clover production tended to be higher from Huia and it was only in the third and fourth years that production from Pitau equalled or exceeded that of Huia. Some differences in seasonal clover production were noted. Huia proved superior in spring and summer, while Pitau generally produced more dry matter in autumn. Production from both clovers was very iow during winter, particularly in June and July.

Pitau appeared to have a more erect and open growth habit than Huia and was shown to be less dense in several instances. This characteristic could be a disadvantage under close grazing and indeed in the one grazing trial Pitau generally did not perform as well as in the two mowing trials. It could also have been one of the factors which made Pitau prone to suppression from ryegrass competition.

While the performance of Pitau was disappointing in the first two years following sowing, its performance in the next two years showed a marked relative improvement and in the Traquair mowing trial clover yields from Pitau were considerably higher than from Huia in the 4th year. Thus a mixture of the two cultivars, to retain the high density and good spring production of the Huia swards along with the superior cool weather production of Pitau, may be worth investigation.

\section{ACKNOWLEDGEMENTS}

The authors wish to acknowledge the help of various staff members of Invert-nay Agricultural Research Centre who assisted with field and laboratory work. Also the Biometrics Section for the statistical analyses and R. J. Reid, Traquair, on whose property one of the trials was situated.

\section{REFERENCES}

Barclay, P. C., 1969: Proceedings of the. N.Z. Grassland Association, 31: $127-34$.

Duncan, D. B., 1955: Biometrics, 11: 1-42.

Lambert, J. P.; Vartha, E. W.; Harris, A. I., 1969: Proceedings of the N.Z. Grassland Association, 31: 135-42.

Lynch, P. B., 1947: N.Z. Journal of Science and Technology, 28A: 385-405.

Weeda, W. C.; Cullen, N. A.; Douglas, I. A.; During, C., 1969: Proceedings of the N.Z. Grassland Association, 31: 143-50. 